\title{
PENTINGNYA PELAYANAN KONSELING PRANIKAH
}

\section{Oleh : Pdt. Anderias Mesak Morib, S.Th., M.Pd.K Dosen STT Erikson - Tritt}

\begin{abstract}
ABSTRAK
Pernikahan merupakan impian semua orang, sebab pernikahan berasal dari Allah melalui Adam dan Hawa. Pernikahan di mata Allah adalah kudus, sehingga setiap orang yang menikah di hadapan Allah adalah kudus. Pernikahan merupakan bahtera rumah tangga yang dikehendaki oleh Allah dan Allah tidak pernah merencanakan adanya perpisahan atau perceraian. Perceraian merupakan produk manusia karena keegoisan manusia itu sendiri. Kenyataannya adalah masih ada banyak rumah tangga Kristen yang hancur sehingga pernikahan mereka harus putus di tengah jalan. Dalam hal inilah konseling pranikah sangat diperlukan oleh pasangan yang akan menikah. Karena pernikahan bukanlah suatu hal yang mudah untuk dipahami, melainkan sesuatu yang sangat penuh rahasia. Tujuan dari pranikah agar setiap pasangan benar-benar memahami dan mengerti arti dari suatu pernikahan yang benar dan sesuai dengan kehendak Allah.
\end{abstract}

\section{Kata Kunci : Pelayanan Konseling, Pranikah}




\section{A. PENDAHULUAN}

Pernikahan merupakan impian bagi setiap insan. Setiap manusia pasti ada keinginan untuk menikah. Pernikahan erat kaitannya dengan rumah tangga, karena setiap orang yang menikah pasti akan memasuki bahtera rumah tangga. Di dunia ini tidak ada satu pun orang yang menginginkan kehancuran dalam rumah tangganya. Semuanya selalu berusaha untuk mengejar dan mewujudkan agar pernikahan mereka tetap baik dan harmonis untuk selamanya.

Tetapi sangat disayangkan, karena pada prakteknya masih banyak rumah tangga yang mengalami kehancuran dan kegoncangan. Hal tersebut disebabkan oleh berbagai faktor. Wanda Humble dan Victor S. Liu dalam bukunya yang berjudul Persiapan Pernikahan Menuju Rumah Tangga yang Bahagia menandaskan bahwa:

Pasangan Anda bukanlah Anda, pria dan wanita adalah berlainan diciptakan dalam rupa dan gambar Allah, bukan menurut rupa dan gambar Anda. Ia layak dijadikan berbeda, diperlukan dan dihargai seperti yang lain. ${ }^{1}$

Dari pendapat di atas, dapat disimpulkan bahwa hal yang paling mudah menyebabkan terjadinya kehancuran dalam rumah tangga adalah perbedaan. Banyak rumah tangga yang digoncang oleh perbedaan. Salah satu contoh yang paling sepele adalah perbedaan pendapat didalam rumah tangga. Hanya karena perbedaan tersebut banyak rumah tangga yang mengalami kehancuran dan lain sebagainya.

Bahkan hampir setiap hari kita bisa melihat kasus tentang kegoncangan rumah tangga melalui Siaran Televisi. Dimana disana ada banyak pasangan suami isteri yang mengalami kegoncangan dalam rumah tangga mereka. Salah satu contoh adalah pasangan para selebriti, bahkan yang lebih menyedihkan lagi orang-orang Kristen pun termasuk didalamnya.

Selain hal tersebut diatas masih banyak lagi hal-hal yang dapat menghancurkan kebahagiaan atau keharmonisan di dalam rumah tangga. Pdt. J. D. Engel, M.Si dalam bukunya yang berjudul teladan kehidupan mengemukakan bahwa:

\footnotetext{
${ }^{1}$ Wanda Humble dan Victor S. Liu, Persiapan Pernikahan Menuju Rumah Tangga Yang Bahagia (Yogyakarta: Sekolah Tinggi Theologia Injili Indonesia, 1997), hlm. 15.
} 
Taraf hidup keluarga menjadi sejahtera bila tercapai keseimbangan antara kebutuhan keluarga dengan penghasilan keluarga. Kebahagiaan dalam keluarga tercapai bila ada keseimbangan antara kebutuhan jasmani dan rohani. Apabila tidak terjadi keseimbangan tersebut maka akibatnya rumah tangga akan mengalami kegoncangan, kesulitan, keretakan, dan akibat-akibat negatif lainnya yang dapat mempengaruhi kesejahteraan spritual maupun sosial lainnya. $^{2}$

Dari pernyataan di atas, ada dua hal yang harus diperhatikan di dalam rumah tangga yaitu: keseimbangan antara kebutuhan jasmani dan rohani. Dimana keduanya haruslah diatur dengan seimbang. Jadi tidak ada alasan bagi pasangan suami isteri untuk lebih mengutamakan, mengejar atau mengedapankan satu faktor saja untuk mewujudkan atau mengejar keharmonisan dalam rumah tangga sehingga mengabaikan yang lain. Sering orang berpendapat bahwa apabila banyak harta dan semua kebutuhan rumah tangga terpenuhi maka bahagialah rumah tangga tersebut. Ini adalah konsep yang keliru. Dalam hal inilah konseling pranikah sangat diperlukan oleh pasangan yang akan menikah. Karena pernikahan bukanlah suatu hal yang mudah untuk dipahami, melainkan sesuatu yang sangat penuh rahasia. Namun di sisi lain konseling pranikah dibutuhkan oleh karena pemuda-pemudi atau calon pasangan suami isteri yang akan menikah tersebut belum begitu banyak mengetahui tentang hal apa saja yang harus dipersiapkan sebelum mereka menikah.

Dengan melihat latar belakang tersebut diatas maka penulis memandang perlu untuk membahas "Pentingnya pelayanan konseling pranikah Karena pada saat sekarang ini kebanyakan orang menikah bukan didasari oleh kasih, tetapi didorong oleh hawa nafsu:

Menurut salah satu jemaat GKAI Maranatha, Andarius Saroy mengatakan: kebanyak memilih pasangan karena melihat cantik, menarik, tidak melalui tahap dalam pacaran tetapi langsung melampiaskan keinginan dagingnya mengakibatkan kecelakaan dini. ${ }^{3}$

${ }^{2}$ Pdt. J. D. Engel, M.Si, Teladan Kehidupan (Yogyakarta: Andi Offset, 2006), hlm. 1:79.

${ }^{3}$ Andarius Saroi, Jemaat GKAI Maranatha Taman Ria. Hari Minggu, Tgl. 12 Juli 2014. 
Hal ini membuat sehingga banyak pemuda-pemudi yang sudah masuk dalam bahtera rumah tangga, tidak begitu paham tentang pengertian rumah tangga yang ideal menurut Alkitab. Menurut Alkitab, pernikahan dalam dunia kekristenan adalah suatu persekutuan antara seorang laki-laki dan perempuan berdasarkan pada ketetapan Allah sendiri (Kej. 2:18, 21-22), dan pernikahan juga adalah suatu lembaga yang didirikan oleh Allah melalui manusia pertama yakni Adam dan Hawa, sehingga pernikahan bertujuan untuk kemuliaan bagi nama Tuhan, melalui keluarga yang dibentuk dalam suatu pernikahan yang kudus itu.

Gereja yang berada dalam lingkungan masyarakat juga kurang begitu mempersiapkan calon keluarga Kristen untuk hidup sesuai dengan Firman Tuhan. Karena fakta membuktikan bahwa pada masa sekarang ini sering banyak dijumpai pasangan suami isteri yang baru menikah sudah meminta cerai. Menurut Pengamatan dan Penelitian bahwa, Bimbingan Pranikah hanya dilakukan dalam satu atau dua hari saja karena keadaan yang sangat mendesak karena sudah hamil. ${ }^{4}$ Ini semua disebabkan karena kebiasaan hidup pergaulan dan adat, kebiasaan yang membentuk kehidupan sehingga tidak lagi menjaga hidup sesuai dengan Firman Tuhan sehingga kurangnya bimbingan Pendidikan Kristen secara khusus kepada para calon pasangan suami isteri tersebut sebelum memasuki pernikahan (memasuki bahtera rumah tangga).

Pendidikan Agama Kristen kurang mengerti makna pernikahan, tetapi berani menikah, mengakibatkan kehancuran rumah tangga, terpecah belah hubungan pernikahan terus-menerus tidak berhenti terjadi dalam dunia ini. ${ }^{5}$ Sedangkan pernikahan adalah pernikahan yang terjadi atas inisiatif Allah sendiri, karena Allah yang menentukan pernikahan tersebut. Lebih jelasnya ada Ayat Firman Tuhan berkata: Tuhan Allah berfirman: "Tidak baik, kalau manusia itu seorang diri saja. Aku akan menjadikan penolong baginya, yang sepadan dengan dia. $^{6}$

${ }^{4}$ Zet Luther Rumawak, Majelis Jemaat GKAI Maranatha Taman Ria. Hari Minggu Tgl 12

${ }^{5}$ Stephen Tong, Keluarga Bahagia (Jakarta: Lembaga Reformed Injili Indonesia, 1995), hlm. 36-37.

${ }^{6}$ Kejadian 2:18. 
Firman Tuhan diatas jelas sekali mengatakan bahwa pernikahan itu didasari oleh Allah. Sudah direncanakan oleh Allah, artinya pernikahan bukanlah ajang coba-coba.

\section{Tujuan Konseling Pranikah}

Proses konseling adalah suatu usaha untuk mencapai tujuan. Tujuan ini tidak lain adalah perubahan yang diharapkan pada diri konseli, baik itu secara sikap, bentuk pandangan, keterampilan yang akan memungkinkan konseli itu dapat menerima diri sendiri, mengambil keputusan dan mengarahkan dirinya sendiri serta pada akhirnya si konseli itu dapat mewujudkan dirinya sendiri dengan optimal. Demikian juga halnya dengan konseling Pranikah, ada tujuan tertentu yang akan dicapai. Di bawah ini akan penulis paparkan tujuan pelayanan Konseling Pranikah.

\section{Membimbing Calon Pasangan Suami Isteri Kepada Kedewasaan}

Salah satu tujuan dari Konseling Pranikah adalah membimbing calon pasangan suami isteri untuk menuju kedewasaan. Kedewasaan yang dimaksud di sini adalah kedewasaan rohani. Allah menghendaki setiap orang Kristen mengalami pertumbuhan dan kedewasaan secara rohani karena hal ini akan membuktikan bahwa orang Kristen semakin dekat dengan Tuhan. Pentingnya kedewasaan rohani dialami oleh pasangan suami isteri adalah untuk memotivasi mereka terlibat di dalam melayani Tuhan. Salah satu cara dalam mendorong pasangan suami isteri untuk terlibat dalam melayani sesuai dengan talenta dan karunia yang diberikan oleh Tuhan adalah melalui bimbingan Konseling Pranikah. Memang ini bukan satu-satunya cara untuk mendewasakan rohani mereka, apalagi waktu yang dibutuhkan dalam Konseling ini begitu singkat, tapi paling tidak melalui pelayanan Konseling Pranikah ini dapat memberikan gambaran bagaimana maksud dan rencana Tuhan atas Keluarga Kristen. Allah menginginkan supaya Keluarga Kristen juga terlibat dalam melayani di ladang-Nya.

Keluarga merupakan unit terkecil dari masyarakat dan merupakan pengayom kehidupan yang mempunyai fungsi 
keagamaan, kebudayaan, perlindungan, pembinaan reproduksi,cinta kasih, dan memberikan makna kehidupan serta mengaktualisasikan diri untuk menjadi saksi Kristus serta menjadi pelayan Kristus. ${ }^{7}$

Selain pasangan suami isteri terlibat dalam melayani, agar mereka juga selalu membangun hubungan dengan Tuhan sebagai bentuk kedewasaan rohani yang mereka miliki melalui komunikasi yang baik dengan Tuhan lewat Doa.

\section{Menyarankan Calon Pasangan Suami Isteri Supaya Memperoleh Anak}

Pasangan suami isteri yang memutuskan untuk memasuki bahtera rumah tangga, berarti sudah memikirkan secara matang kesiapankesiapan mengenai kehidupannya yang akan datang. Termasuk kesiapan akan memperoleh anak. Alkitab dengan jelas menyatakan bahwa: "Manusia itu harus beranak cucu memenuhi bumi"(Kej. 1:27). Ada beberapa para pasangan suami isteri yang takut akan memperoleh anak, alasannya karena keadaan ekonomi yang belum memenuhi target. Memang ada juga yang belum di karunia oleh Tuhan. Tetapi harus kita ketahui bahwa tujuan Allah mempersatukan laki-laki dan perempuan dalam ikatan pernikahan salah satunya adalah supaya mereka memperoleh anak.

Namun perlu di ingat juga bahwa memperoleh anak merupakan salah satu tujuan pernikahan, tetapi bukan satu-satunya tujuan dalam pernikahan. Apabila pernikahan itu semata-mata hanya untuk untuk memperoleh anak atau keturunan, maka suami isteri hanya di-pandang sebagai pabrik atau mesin yang hanya berguna apabila menghasilkan sesuatu, kalau tidak menghasilkan sesuatu, akan dibuang atau tidak terpakai lagi. ${ }^{8}$

Anak-anak dalam Keluarga Kristen adalah milik Tuhan (Mzm. 127:3). Anak-anak adalah milik Tuhan yang dipercayakan kepada orang tua. Anak-anak bukan milik orang tua, tetapi mereka dipercayakan untuk suatu masa dan anak bukan di simpan tetapi di

\footnotetext{
${ }^{7}$ Engel, Teladan Kehidupan, hlm. 1:78.

${ }^{8}$ Humble dan Liu, Persiapan Pernikahan Menuju Rumah Tangga Yang Bahagia, hlm. 9 .
} 
besarkan. ${ }^{9}$ Oleh karena itu orang tua harus mempersiapkan diri dengan baik untuk menyambut, memelihara, dan mendidik anak tersebut. Mempunyai anak tanpa persiapan yang baik merupakan tindakan yang sembrono.

\section{Membawa Calon Pasangan Suami Isteri Memahami Arti Pernikahan}

Banyak orang menikah tanpa memahami arti pernikahan yang sesungguhnya. Hal ini disebabkan karena kurangnya pengetahuan mereka terhadap pernikahan. Pernikahan bukanlah hanya sekedar pemberkatan di Gereja oleh Pendeta atau Pastor, dan juga bukanlah hanya sekedar pesta besar-besaran. Tetapi lebih daripada itu pernikahan adalah sesuatu yang sangat kudus dihadapan Allah. Oleh sebab itu manusia harus menghargai pernikahan karena pernikahan adalah sesuatu yang sudah di rencanakan oleh Allah, bahkan Allah sendiri mengizinkan pernikahan itu terjadi. Alkitab mencatat bahwa: "Tidak baik, kalau manusia itu seorang diri saja. Aku akan menjadikan penolong baginya, yang sepadan dengan dia." ${ }^{10}$ Dari ayat ini kita bisa melihat bagaimana Allah merancang sebuah rencana atas laki-laki (Adam) untuk calon pasangan hidupnya, yaitu perempuan (Hawa).

Hal ini harus benar-benar dipahami oleh setiap orang percaya yang akan memasuki bahtera rumah tangga. Sebab tanpa memahami arti pernikahan yang sesungguhnya, maka pernikahan itu akan di pandang rendah oleh kita. Oleh sebab itu bimbingan atau pelayanan konseling Pranikah sangat diperlukan oleh setiap muda-mudi atau calon pasangan suami isteri yang akan memasuki pernikahan. Dengan dasar itu kita dapat mengerti bahwa pernikahan merupakan kehendak dan persatuan Ilahi, inilah persekutuan yang unik dan indah yang harus selalu disadari dan dipertahankan oleh manusia. ${ }^{11}$

Selanjutnya rasul Paulus juga menekankan hal kemuliaan dan kesucian pernikahan dalam 1 Korintus 6:15, 16 dan Efesus 5:31, dimana kesatuan suami isteri adalah sebagai sesuatu yang dapat

${ }^{9}$ Charles C. Swindoll, Anda dan Anak (Surabaya: YAKIN, 1988), hlm. 61-62.

${ }^{10}$ Kejadian 2:18.

${ }^{11}$ Tim Penyusun, Katekesasi Pernikahan (Magelang: Departement Pembinaan BPMS GKI Jateng, 1990), hlm. 7. 
menggambarkan rahasia hubungan kesatuan antara Yesus Kristus dan Gereja-Nya.

\section{Mengarahkan Calon Pasangan Suami Isteri Supaya Rumah Tangga Kristen Menjadi Berkat Bagi Orang Lain}

Selanjutnya tujuan Konseling Pranikah adalah mengarahkan bagaimana pasangan suami isteri haruslah menjadi berkat bagi orangorang di sekitarnya. Hal ini ditegaskan oleh Tuhan Yesus: "kamu adalah garam dunia. Jika garam itu menjadi tawar, dengan apakah ia di asinkan? Tidak ada lagi gunanya selain dibuang dan diinjak orang dan kamu adalah terang dunia. Kota yang terletak di atas gunung tdak mungkin tersembunyi." 12

Maksud ayat ini adalah supaya setiap orang percaya harus menjadi berkat bagi orang lain, harus mencerminkan kehidupan yang berkenan di hadapan Tuhan, sehingga melalui hidup kita orang bisa merasakan kasih Tuhan. Terlebih pasangan suami isteri yang akan terjun di dalam masyarakat. Hal ini harus diperhatikan sebaik-baiknya, karena semua orang akan melihat bagaimana kehidupan keluarga Kristen di tengahtengah masyarakat. Keluarga Kristen harus bisa dan mampu tampil beda di tengah-tengah kehidupan masyarakat. Oleh sebab itu gereja harus benar-benar memperhatikan hal tersebut, sehingga para calon pasangan suami isteri yang akan memasuki bahtera rumah tangga benar-benar dapat mewujudkan apa yang diinginkan oleh Allah dalam Keluarga.

\section{Memberikan Pemahaman Bahwa Pernikahan Adalah Suatu Persekutuan Hidup Yang Terus Menerus}

Setiap keluarga tidak akan pernah lepas dari problema (masalah), akan tetapi masalah-masalah tersebut tidak bisa dijadikan sebagai alasan untuk mengakhiri pernikahan. Allah sendiri telah memberikan ketetapan mengenai pernikahan (Kej. 2:23-24; Mal. 2:18 dan Mat. 19:6). Allah sangat membenci perceraian, Firman Allah berkata: "Aku membenci perceraian Firman Tuhan Allah Israel."13

\footnotetext{
${ }^{12}$ Matius 5:13-14.

${ }^{13}$ Malekahi 2:16.
} 
Alasan Allah membenci perceraian adalah karena hal itu sangat bertentangan dengan rencana Allah. Dalam Injil Matius 5:31-32 Tuhan Yesus mengajarkan mengenai masalah perceraian, dimana di sana Yesus menekankan bahwa pernikahan itu adalah persekutuan hidup yang terus menerus antara suami isteri. Rasul Paulus kembali menegaskan bahwa Kristus tidak ada pemisahan atau perceraian bagi orang percaya (1 Kor. 7:10). Akan tetapi jika perceraian terjadi, maka Paulus memberikan dua alternatif, yaitu isteri tidak boleh menikah lagi sebelum suaminya meninggal, demikian juga dengan suami tidak boleh menikah lagi sebelum isterinya meninggal.

Pernikahan adalah persekutuan hidup yang harus terjadi secara terus menerus, itu artinya bahwa pernikahan itu tidak hanya untuk beberapa saat saja, tetapi berlangsung terus selama mereka hidup. Allah mengadakan pernikahan bagi manusia supaya pernikahan menjadi suatu persekutuan hidup. ${ }^{14}$ Persekutuan hidup ini mencakup seluruh kehidupan, Tuhan menghendaki agar suami dan isteri menjadi satu. Satu di dalam kasih Tuhan, satu dalam kasih seorang terhadap yang lain, satu dalam ketaatansatu dalam memikul beban, dan satu dalam pengabdian kepada Tuhan. ${ }^{15}$

Itulah sebabnya pelayanan konseling Pranikah di berikan kepada para calon pasangan suami isteri dengan tujuan supaya mereka benarbenar mengerti dan memahami arti pernikahan yang dikehendaki oleh Allah dalam Keluarga Kristen. Sehingga mereka benar-benar menjadi pasangan sauami isteri yang berkenan dihadapan Tuhan.

\section{Pokok Pengajaran Dan Metode Pelayanan Konseling Pranikah}

Di dalam suatu pelayanan pasti ada sasaran atau pokok-pokok yang menjadi target untuk diajarkan, baik itu berkhotbah, mangajar, maupun penginjilan. Demikian juga dengan pelayanan Konseling Pranikah. Untuk mencapai sasaran pokok-pokok tersebut tidaklah mudah, sehingga untuk mempermudah pencapaian sasaran pokokpokok yang akan diajarkan sangat dibutuhkan suatu cara atau metode.

\footnotetext{
${ }^{14}$ J. L. CH. Abineno, Manusia Suami Dan Isteri, Perkawinan Dan Keluarga (Jakarta: BPK Gunung Mulya, 1992), hlm. 30.

${ }^{15}$ Ibid., hlm. 33,
} 
Di bawah ini penulis akan membahas pokok-pokok pengajaran dan metode tentang pelayanan Konseling Pranikah. Pada bagian ini Penulis akan menjelaskan beberapa pokok pikiranatau Pokok pengajaran tentang pelayanan Konseling Pranikah. Ada beberapa pokok-pokok penting yang diajarkan di dalam pelayanan konseling Pranikah. Adapun pokok-pokok tersebut adalah sebagai berikut:

\section{a. Dasar Dan Tujuan Pernikahan}

Setiap calon pasangan suami isteri yang akan menikah tanpa memahami dasar dan tujuan pernikahan yang sesungguhnya bersadarkan kebenaran Alkitab, maka akan terjadi hal-hal yang akan menimbulkan kegoncangan dalam rumah tangga mereka. Oleh sebab itu, di dalam pelayanan konseling Pranikah harus diajarkan kepada para calon pasangan suami istri, supaya tatkala mereka sudah memasuki bahtera rumah tangga mereka bisa menerapkan hal tersebut di dalam kehidupan rumah tangga mereka.

Alkitab memberikan kesaksian mengenai dasar dan tujuan pernikahan Kristen yang sesungguhnya. Menurut kesaksian Perjanjian Lama adalah sebagai berikut: Allah telah menciptakan manusia menurut gambarnya sebagai pria dan wanita. Lalu memberkati mereka dan memberi tugas panggilan kepada mereka. Sebagai "gambar Allah" berarti manusia mempunyai hubungan khusus dengan Allah, dan sebagai pria dan wanita mempunyai kedudukan yang sama dihadapan Allah.sejak semula pria dan wanita diciptakan sebagai satu kesatuan dan hidup dalam persekutuan.

Dari pernyataan di atas kita dapat melihat bahwa dasar pernikahan Kristen adalah sebagai gambar Allah, artinya sebagaimana hubungan antara Allah dengan manusia merupakan satu kesatuan, demikianlah pasangan suami isteri harus merupakan satu kesatuan di dalam persekutuan. Jadi dasar pernikahan Kristen yang sesungguhnya adalah untuk membentuk persekutuan antara sesama anggota Keluarga kepada Allah.

Karena pernikahan itu pada dirinya sudah merupakan suatu kesatuan yang lengkap dimana suami isteri menjadi sedaging. Ini berarti bahwa pernikahan itu tidak kehilangan maknanya pada dirinya jika tidak dikaruniai atau keturunan. Dengan perkataan lain pernikahan 
sudah mencapai tujuan bila pria dan wanita menjadi satu atau sedaging melalui proses saling memberi, melengkapi dalam suka dan duka.

Oleh karena itu, penciptaan manusia perempuan dari tulang rusuk laki-laki lebih menunjukkan kesatuan dua makhluk berbeda jenis kelamin dan bukan perbedaan status. Mereka berkedudukan sama dihadapan Allah, sempurna dan utuh dalam kebersamaan mereka. Dengan demikian mereka harus saling melengkapi dan memberi.

\section{b. Hidup Sebagai Suami Isteri}

Pernikahan adalah suatu ikatan yang unik dan istimewa antara seorang pria dengan seorang wanita, yang diciptakan oleh Allah untuk membawa pasangan suami isteri itu bersama anak-anaknya kepada kehidupan keluarga yang bahagia. Disamping itu, pernikahan sendiri adalah suatu persekutuan dari dua manusia yang mempunyai banyak perbedaan dari banyak faktor sehingga terbuka kemungkinan timbul masalah-masalah pernikahan yang kompleks.

Dikalangan orang-orang Kristen sering tidak merasakan ketidakbahagiaan dalam rumah tangganya, tidak pernah mengalami kedamaian secara lahir maupun batin, itu semua disebabkan karena status suami isteri yang tidak jelas. Hidup sebagai suami istri adalah salah satu bentuk kehidupan bersama yang berbeda dari bentuk-bentuk kehidupan bersama lainnya, misalnya persahabatan, kawan sekerja dan lain sebagainya. Hal ini disebabkan oleh adanya kenyataan bahwa kehidupan bersama dalam pernikahan bersifat total, tertutup dan terus menerus. Artinya dalam pernikahan, suami istri hidup dalam suatu persekutuan yang mencakup seluruh kehidupan, terbatas antara satu pria dan satu wanita saja, dan terjadi secara terus menerus sampai akhir hayat seseorang. Disamping itu dasar kehidupan bersama mereka adalah kasih Kristus.

Suami isteri dalam pernikahan sebenarnya telah dipersatukan oleh Allah. Bahkan mereka disebut "bukan lagi dua tetapi satu." Walaupun demikian, di dalam pernikahan suami isteri tetaplah merupakan dua pribadi yang berbeda, yang mempunyai latar belakang keluarga yang berbeda, minat yang berbeda, kebiasaan yang berbeda, dan sebagainya. Dua orang yang menikah tetaplah dua manusia yang unik, yang memiliki kekhasan masing-masing. 
Oleh karena itu, dalam membina kehidupan bersama dalam pernikahan perlu diperhatikan kesatuan di tengah-tengah perbedaan mereka sebagai pribadi. Untuk itu suami isteri perlu mengerti dan mengenal peran mereka dalam perbedaan keberadaan mereka sebagai pria dan wanita.

\section{b.1. Peran Suami}

Dalam kehidupan sehari-hari kita sering menyaksikan hubungan yang tidak seimbang dalam pernikahan karena suami lebih berperan sebagai atasan, dan isteri lebih berfungsi sebagai bawahan. Suami dipandang lebih tinggi kedudukannya daripada isteri. Padahal Alkitab mengajarkan suami dan isteri mempunyai kedudukan yang sama dihadapan Allah. Di dalam Kristus tidak ada laki-laki atau perempuan, artinya tidak ada perbedaan status atau kedudukan diantara manusia dalam dunia baru yang mulai dihadirkan oleh Kristus.

Disamping kenyataan bahwa di dalam Kristus tidak ada perbedaan status dan kedudukan, perlu disadari bahwa di dalam pernikahan ada perbedaan keberadaan psikis dan peran yang perlu diselaraskan. Suami harus (yang pada dirinya punya kemampuan) mengasihi isterinya, sebab keberadaan isterinya sebagai wanita yang selalu membutuhkan sikap dan perlakuan kasih dari suaminya. Sedangkan isteri harus tunduk kepada suaminya. Sebab suami membutuhkan sikap dan perlakuan hormat dari isterinya.

Berdasarkan status atau kedudukan yang sama dan adanya perbedaan keberadaan diantara keduanya, maka penulis akan membahas peran masing-masing suami isteri yang paling penting dalam rumah tangga. Firman Tuhan berkata bahwa:

Hai suami, kasihilah isterimu sebagaimana Kristus telah mengasihi jemaat dan telah menyerahkan diri-Nya baginya untuk menguduskannya, sesudah Ia menyucikannya dengan memandikannya dengan air dan firman, supaya dengan demikian Ia menempatkan jemaat dihadapan diri-Nya dengan cemerlang tanpa cacat atau kerut atau yang serupa itu tetapi supaya jemaat kudus dan tidak bercela. Demikian juga suam 
harus mengasihi isterinya sama seperti tubuhnya sendiri:siapa yang mengasihi isterinya mengasihi dirinya sendiri. ${ }^{16}$

Kasih yang dimaksud Allah di sini adalah kasih yang dinyatakan tanpa pamrih. Jadi suami harus mengasihi isteri tanpa pamrih, tanpa syarat, karena kasih yang diberikan suami biasanya identik dengan kasih yang diberikan oleh Yesus Kristus. Karena suami disamakan pada kedudukan Kristus, sebagaimana Krsitus mengasihi jemaat-Nya, maka demikian juga suami harus mengasihi isteri dan anak-anaknya sebagaimana suami menjadi kepala dari isteri dan anak.

Disamping mengasihi isteri dan anak-anaknya, suami juga harus bertanggung jawab terhadap kerohanian isteri dan anak-anaknya. Tugas ini memang berat karena status suami diibaratkan dengan status Kristus terhadap jemaat-Nya. Suami harus hidup bijaksana dan menghormati isteri (1 Ptr. 3:7). Suami bijaksana di sini berarti penuh pengertian, dan suami tidak berlaku kasar terhadap isteri (Kol. 3:19). Suami juga harus bertanggung jawab atas kebutuhan isteri dan anak-anaknya. Sebagai orang tua atau suami pada khususnya, Alkitab mengatakan bahwa: Dan kamu bapa-bapa janganlah bangkitkan amarahmu di dalam hati anakanakmu, tetapi didiklah mereka di dalam ajaran dan nasehat Tuhan. Hai bapa-bapa jangan sakiti hati anakmu, supaya jangan tawar hatinya. ${ }^{17}$

Berdasarkan ayat di atas bahwa sebagai suami, Firman Tuhan menegaskan bahwa dia tidak boleh membangkitkan amarah dan jangan menyakiti hati anak, juga dituntut supaya mendidik anak-anak dalam moralnya, dan memberikan teladan. Dalam hal memberikan teladan kepada anak-anak, Clyde narramore dalam bukunya yang berjudul menolong Anak bertumbuh dalam Iman, mengatakan bahwa: Anakanak, muda khususnya remaja cepat sekalimenyadari apakah orangctuanya hidup bagi Allah atau tidak. Dan kehidupan mereka dibentuk oleh hal ini. Orangtua harus mempunyai kehidupan yang konsekuen dihadapan anak-anakan mereka. ${ }^{18}$

Melalui pernyataan di atas bahwa kejujuran orang tua akan mempengaruhi perumbuhan mereka, karena orang tua bagi mereka adalah teladan dalam hidup mereka. Orang tualah yang paling dekat

${ }^{16}$ Efesus 5:25-28.

${ }^{17}$ Kolose 3:21.

${ }^{18}$ Clyde Narramore, Menolong Anak Anda Bertumbuh Dalam Iman (Bandung: Kalam Hidup, t.t). hlm. 28. 
dengan aanak-anaknya. Oleh sebab itu sebagai orang tua, suami harus menjadi teladan bagi anak-anaknya.

\section{b. Peran Isteri}

Selain suami, Isteri juga sangat mempunyai peran penting dalam kehidupan rumah tangga. Sebagai isteri, Firman Tuhan berkata bahwa: Hai isteri tunduklah kepada suamimu seperti kepada Tuhan karena suami adalah kepala isteri sama seperti Kristus adalah kepala jemaat. Dialah yang menyelamatkan tubuh. karena itu sebagaimana jemaat tunduk kepada Kristus, demikian jugalah isteri kepada suami dalam segala sesuatu. ${ }^{19}$

Ayat di atas jelas sekali memberikan kontribusi kepada kita bahwa sebagai isteri haruslah memahami akan tugas dan tanggung jawabnya kepada suami. Karena banyak para isteri yang tidak mengerti akan posisinya di dalam rumah tangga, bahkan berani mengatur suami dalam segala hal.

Alkitab memberi kesaksian bahwa wanita diciptakan oleh Allah adalah untuk menolong laki-laki (Adam). Posisi ini diberikan oleh Allah sebelum manusia jatuh ke dalam dosa, bahkan ketika manusia jatuh ke dalam dosa pun posisi ini tetap tidak ada perubahan. Yang dimaksud tanggung jawab dalam posisi di sini adalah: isteri sebagai penolong, tunduk terhadap suami, menghormati suami, dan pengurus keluarga. ${ }^{20}$ Dalam hal ini perempuan sangat memiliki nilai yang tinggi, sama dengan nilai yang dimiliki laki-laki, karena dimata Allah perempuan sangat berharga juga. Oleh sebab itu, dalam rumah tangga isteri harus bisa menempatkan posisinya sebagaimana yang diajarkan olah Alkitab, agar tidak terjadi hal-hal yang dapat membuat keretakan hubungan istri dalam rumah tangga.

\section{Kehidupan Seksual}

Hidup sebagai suami isteri juga ditandai dengan adanya hubungan seksual. Menurut pandangan Iman Kristen, seks adalah anugerah Tuhan

\footnotetext{
${ }^{19}$ Efesus 5:22-23.

${ }^{20}$ Jonathan A. Trisna, Pernikahan Kristen (Jakarta: Institut Theologia dan keguruan Indonesia, 2000), hlm. 213.
} 
yang diberikan kepada manusia sejak manusia diciptakan. Oleh sebab itu seks bukanlah hal yang kotor, tabu dan berdosa, sebab seks diberikan oleh Allah (Kej. 1:27). Pemberian seks dari Allah tersebut dimaksudkan agar manusia dapat mengungkapkan cinta kasih sepenuhnya sebagai suami isteri dalam pernikahan dan dapat meneruskan keturunan.

Hubungan seks merupakan aspek yang penting dalam hidup pernikahan. Firman Tuhan sendiri menasehatkan agar suami isteri melakukan hubungan seksual (1 Kor. 7:3-4). Walaupun demikian, hubungan seks bukan merupakan satu-satunya cara mengungkapkan kasih dalam pernikahan dan bukan pula satu-satunya sumber kebahagiaan dalam pernikahan. ${ }^{21}$

Dalam hidup sehari-hari sering dijumpai suami isteri yang masih merasakan kebahagiaan dalam pernikahan walaupun mereka jarang atau bahkan tidak lagi melakukan hubungan seksual. Seks diciptakan oleh Allah sama seperti menciptakan lapar dan haus. Jadi seks itu adalah baik, wajar, dan sesuai dengan kehendak Allah bagi manusia. Seks dijadikan oleh Allah supaya maksud-maksud yang baik dapat diwujudkan, yaitu supaya pernikahan diwujudkan oleh hubungan kelamin antara suami dan isteri. Manusia diciptakan oleh Allah sebagai makhluk seksual (Kej. 1:27). Memang sangat penting untuk diketahui bahwa berhubungan seks hanya dapat dilakukan ketika sudah masuk dalam jenjang pernikahan. Lebih lanjut Scheunemann berkata bahwa: "Berhubungan seks sebagai ekspresi kesatuan kasih yang hanya dilakukan dibawah kemah nikah, melalui hubungan seks masingmasing akan saling menolong, baik laki-laki, maupun perempuan dalam arti yang khusus serta penuh rahasia." 22

Pernyataan dengan jelas berkata bahwa antara suami isteri harus saling membahagiakan antara satu sama lain. Dan kunci rahasia kebahagiaan semua ini tidak terlepas dari terbentuknya komunikasi yang indah antara suami isteri, yang bermanfaat untuk memberikan kebahagiaan diantara mereka dalam hal membagikan beban, menyatakan kasih baik itu secara batin maupun lahir terutama sekali dalam melakukan hubungan seks.

\footnotetext{
${ }^{21}$ Engel, Teladan Kehidupan, hlm. 1:137.

${ }^{22}$ Scheunemann, Hidup Sebelum Dan Sesudah Nikah (Malang: YPP II, 1977), hlm. 213.
} 
Salah satu sumber masalah dalam pernikahan adalah masalah seks, walaupun seks bukan merupakan satu-satunya sumber primer. Biasanya apabila ada masalah mengenai seks antara suami isteri, masalah itu merupakan gejala yang akan menimbulkan masalah yang lebih besar. Oleh sebab itu masalah kehidupan seksual harus menjadi perhatian yang serius dalam kehidupan pernikahan. Karena hal ini adalah kebutuhan biologis yang tidak dapat dipungkiri oleh setiap pasangan suami isteri.

\section{Pendidikan Anak}

Pertanggung jawaban keluarga menuju keluarga sejahtera/harmonis tidak cukup hanya dengan membatasi jumlah anak sebagai keputusan etis yang tepat. Tetapi selanjutnya harus dipikirkan bagaimana mendidik anak-anak itu. Pendidikan anak dalam keluarga yang mencakup "Pendidikan hidup" merupakan aspek yang melengkapi usaha orang tua untuk menuju keluarga yang sejahtera/harmonis.

Dalam Efesus 6:4 berkata bahwa "Dan kamu, bapa-bapa, janganlah bangkitkan amarah di dalam hati anak-anakmu, tetapi didiklah mereka di dalam ajaran dan nasehat Tuhan." ${ }^{23}$ Ayat ini membicarakan suatu tanggung jawab orang tua terhadap anak-anaknya. Anak tidak cukup hanya dipenuhi kebutuhannya setiap hari dan dibiarkan bertumbuh begitu saja secara proses ilmiah, sehingga menjadi besar dan dewasa dan seterusnya. Tetapi Alkitab mengajarkan bahwa di dalam keluarga Kristen, para orang tua dipanggil untuk menjalankan tugas dan tanggung jawabnya.

Ralph M.Rigs dalam bukunya yang berjudul Gembala sidang berhasil, mengatakan bahwa: "Meskipun kita memperhatikan hal-hal rohani dan kesejahteraan orang lain, itu tidak dapat menembus atau mengimbangi pengabaian tanggung jawab kita terhadap anak-anak." 24

Kehadiran anak di tengah-tengah keluarga, merupakan kebahagiaan tersendiri, karena anak itu adalah dari Tuhan bagi keluarga (Ams. 17:6). Lebih-lebih kalau anak itu bijak, terdidik, tahu disiplin, dan hidup benar dihadapan Tuhan. Hal ini merupakan harapan bagi orang tua (Ams. 10:1). Tetapi sebaliknya akan menjadi duri bagi orang

\footnotetext{
${ }^{23}$ Efesus 6:4.

${ }^{24}$ Ralph M.Rigs, Gembala Sidang Yang Berhasil (Malang: Gandum Mas, 1948), hlm. 38 .
} 
tua apabila anak-anak tidak taat, tidak menghargai orang tua, dan tidak menghormati orang tua (Ams. 17:25). Itulah sebabnya, penting sekali bagi orang tua menjalankan tugas dan tanggung jawabnya yang benar dihadapan Tuhan dan terhadap anak-anaknya. Tanggung jawab orang tua terhadap anak-anaknya ialah mengajar atau mendidik mereka di dalam Tuhan.

Sesuai dengan Firman Tuhan, sudah menjadi kewajiban bagi orang tua untuk mendidik atau mengajar anak-anaknya, terutama dalam ketetapan Tuhan. Hal ini bertujuan agar mereka bisa hidup benar dihadapan Tuhan berdasarkan Firman Tuhan dan tidak menyimpang dari kehendak-Nya (U1. 6:7; dan 11:19). Orang tua seringkali disibukkan oleh pekerjaan atau tugas-tugas di luar rumah, sehingga kurang memperhatikan, bahkan tidak sama sekali memperhatikan pendidikan anak-anak mereka. Banyak orang tua berpikir/beranggapan bahwa anak kalau sudah besar disekolahkan di sekolah umum sudah cukup. Tidaklah heran, mengapa ada anak-anak di dalam keluarga Kristen kehidupannya tidak menjadi teladan yang baik dalam segi kehidupan. Pendidikan anak di sekolah tidaklah dengan pendidikan anak di rumah. Suryaprawata mengatakan bahwa:

Perlu disadari bagi keluarga Kristen bahwa pendidikan yang paling dasar ialah pendidikan dalam keluarga. Maka bagaimana pun juga perlu diciptakan suasana yang membahagiakan kelurga. Cerita suci dalam kehidupan kisah dari kitab suci bila mungkin diceritakan oleh bapak/ibu kepada anak-anaknya ada kesempatan yang baik. Anak kecil tidak cukup hanya dilatih berdoa, tetapi juga dilatih memperhatikan kepentingan orang, menghormati kepribadian orang lain, agar kelak tahu melayani kebutuhan orang lain. Teladan orangtua banyak menentukan dalam hal ini. ${ }^{25}$

Pendidikan dalam keluarga adalah pendidikan dasar bagi anak. Dari sini sangat menentukan bagi perkembangan daya nalar anak. Tentunya bukan melalui kekerasan, ataupun dengan kehendak orang tua sendiri. Tujuan dari upaya mendidik anak adalah membawa mereka pada tingkat kedewasaan yang menyanggupkan seorang anak untuk

${ }^{25}$ Suryaprawata, Keluargaku (Yogyakarta: Kanisius, 1992), hlm. 312. 
membuat keputusan-keputusan yang bertanggung jawab. ${ }^{26}$ Hal ini sebenarnya merupakan cerminan dari tata nilai serta sikap yang benar yang dianut orang tua mereka. Kedua orang tua mereka adalah guru yang paling penting. ${ }^{27}$ Mereka diperintahkan Allah untuk mengajar anak-anak mereka setiap hari di dalam keluarga dengan perkataan dan melalui teladan mereka.

Suami isteri yang telah dikaruniai seorang anak, mereka adalah merupakan segitiga yang suci. Persekutuan suami isteri menjadi keluarga/rumah tangga atas kehendak Allah tidak ada taranya di dunia ini. Oleh sebab itu, melalui persekutuan inilah hendak dipakai oleh Allah bagi kepentingan anak-anak. Tuhan menghendaki supaya anakanak mulai belajar tentang Dia.

Kesan yang paling mendalam bagi hidup anak diterimanya pada waktu mereka bergaul erat dengan kedua orang tuanya. Oleh sebab itu, sangat penting apabila orang tua mendidik anak-anaknya dengan roh kasih yang sejati. Orang tua adalah guru dan pendidik yang sejati, yang pertama kali dikenal oleh anak-anak.

\section{Tugas Panggilan Keluarga Kristen}

Pembentukan keluarga Kristen tidak lepas dari kehidupan Gereja/jemaat-Nya, oleh karena itu keluarga merupakan organisasi integral dari Gereja. sebagai bagian dari Gereja, keluarga tidak dapat dilepaskan dari tugas panggilan Gereja di tengah dunia. Dengan demikian panggilan keluarga Kristen dapat dilihat dari tiga segi, yaitu keluarga, gereja, dan masyarakat.

\section{Tugas Panggilan Dalam Keluarga}

Sebelum memasuki pernikahan sebaiknya kedua calon pasangan suami isteri sudah memikirkan secara serius dan terbuka mengenai keluarga yang akan dibentuk bersama. Di zaman modern ini akan banyak masalah-masalah kehidupan keluarga yang akan menggoncang

\footnotetext{
${ }^{26}$ Margareth Baily Jacobsen, Ketika Anak Anda Bertumbuh (Bandung: Kalam Hidup, 1992), hlm. 17.

${ }^{27}$ Daniel Alexander, Pemulihan Keluarga Masa Kini (Yogyakarta: Yayasan Andi, 2001), hlm. 40.
} 
keharmonisan dalam rumah tangga. Masalah-masalah itu harus digumuli dalam iman dan pemikiran yang rasional realistis. Tugas ini janganlah dipandang remeh. Segi lain yang juga perlu diperhatikan ialah memelihara hubungan antar keluarga dalam arti lebih luas yaitu hubungan famili agar hubungan kesatuan keluarga bisa dihayati dan dinikmati. Tugas semacam ini juga perlu diusahakan dengan sungguhsungguh sebagai kesaksian kristiani.

Manusia diciptakan dalam lingkungan keluarga bahkan lebih dari separuh umur manusia berada dalam lingkungan keluarga. Sebagai orang yang telah dipulihkan hubungannya dengan Allah, pastilah kita akan memprioritaskan hubungan keluarga kita dalam kasih Allah yang telah menyelamatkan hidup pernikahan kita. Bahkan lebih dari itu kita juga harus memelihara perhatian terhadap suami, isteri, dan anak-anak dalam kebersamaan. Oleh sebab itu, pasangan suami isteri harus benarbenar memahami tugas dan tanggung jawab mereka di dalam kehidupan keluarga agar selalu tercipta suasana yang harmonis, sejahtera, dan bahagia seperti yang dikehendaki oleh Allah di dalam keluarga Krsiten.

\section{Tugas Panggilan Terhadap Gereja}

Keluarga Kristen sebagai bagian dari jemaat mempunyai tugas panggilan yang mulia dalam kehidupan jemaat. Orang yang telah menerima karya penyelamatan Allah tentu memiliki persekutuan dengan Allah. Sekalipun sebelumnya hubungan itu sempat terputus karena dosa. Hubungan kita dengan Allah meliputi keberadaan kita sebagai manusia yang utuh. Hubungan manusia yang sudah dipulihkan itu adalah anugerah Tuhan semata, sebab Dia yang terlebih dahulu mengasihi dan mencari manusia, dan berinisiatif untuk memelihara hubungan persekutuan dengan umat-Nya. Hal ini penting sekali bagi kesejahteraan keluarga itu sendiri, karena nilai-nilai dan pengalaman iman dalam persekutuan itu dapat memperkaya kehidupan keluarga.

Kehidupan keluarga membutuhkan spiritualitas karena keluarga secara bersama-sama dipanggil untuk saling berhubungan dengan orang lain, dengan Allah, dan dengan dunia/alam semesta. ${ }^{28}$ Keluarga menjadi wadah kehidupan dimana setiap pribadi yang ada di dalamnya

${ }^{28}$ Jonathan A. Trisna, Konseling Pranikah (Malang: Penerbit Gandum Mas, 1987), hlm. 67. 
didorong dan dibantu untuk mengembangkan bakat dan talentanya, sehingga semuanya itu dapat dikembangkan melalui pelayananpelayanan yang sudah menanti di dalam gereja.

Seperti yang dikatakan oleh Marulak Pasaribu, dalam bukunya yang berjudul "Pernikahan dan Keluarga Kristen bahwa: Setiap orang percaya dipanggil untuk melayani, diselamatkan untuk untuk melayani, diciptakan untuk melayani, diberi karunia untuk melayani, diberi kuasa untuk melayani, diperintahkan untuk melayani, disiapkan untuk melayani, dibutuhkan untuk melayani, dan diberi upah menurut pelayanan masing-masing. ${ }^{29}$

Dari pernyataan di atas kita dapat menyimpulkan bahwa, sikap seperti itulah yang harus dimiliki oleh setiap keluarga Kristen, jiwa yang mau melayani, berkorban untuk melayani.

\section{Tugas Panggilan Dalam Kehidupan Masyarakat}

Sebagai bagian dari masyarakat, bangsa dan negara, keluarga Kristen harus bisa menempatkan diri dengan baik dan bertanggung jawab atas lingkungannya. Disinilah keluarga Kristen mendapat kesempatan yang luas untuk memberi kesaksian dan pelayanan Kristiani sesuai dengan Tri tugas gereja, yaitu persekutuan, kesaksian, dan pelayanan. ${ }^{30}$ Dengan demikian keluarga di tengah lingkungannya bisa berfungsi sebagai "Terang, garam, dan pendamai" sehingga nama Tuhan dipermuliakan. Partisipasi yang positif dalam kehidupan masyarakat dan negara merupakan satu tugas panggilan bagi setiap keluarga. Kita hidup dalam di dalam dunia tapi bukan dari dunia (Yoh. 17:12-14). Oleh karena itu sambil memegang teguh iman dan identitas Kristen kita wajib memelihara persekutuan tetangga, rasa solidaritas dengan penderitaan masyarakat dan bangsa. Keluarga Kristen adalah bagian dari masyarakat. Ia diutus untuk mendatangkan damai sejahtera, kebahagiaan dan berkat bagi masyarakat, dan tidak boleh bersikap asosial.

\footnotetext{
${ }^{29}$ Dr. Marulak Pasaribu, Pernikahan Dan Keluarga Kristen (Batu: Departement Literatur YPPII, t.t), hlm. 100.

${ }^{30}$ Derek Prince, Faedah Pentakosta (Jakarta: Yayasan Pekabaran Injil IMANUEL, 1993), hlm. 47.
} 


\section{DAFTAR PUSTAKA}

Alkitab. Jakarta: Lembaga Alkitab Indonesia, 2015.

Abineno, J. L. CH. Manusia Suami Dan Isteri, Perkawinan Dan Keluarga. Jakarta: BPK Gunung Mulia, 1992.

Alexander, Daniel. Pemulihan Keluarga Masa Kini. Yogyakarta: Yayasan Andi, 2001.

Engel, Pdt. J. D. Teladan Kehidupan. Jilid. 1. Yogyakarta: Andi Offset, 2006.

Hasugian, Johanes Waldes. "Kurikulum Dan Pembelajaran Warga Jemaat Dewasa Di Gereja." KURIOS (Jurnal Teologi dan Pendidikan Agama Kristen) 5, no. 1 (2019): 36-53.

Humble, Wanda dan Vi ctor S. Liu. Persiapan Pernikahan Menuju Rumah Tangga Yang Bahagia. Yogyakarta: Sekolah Tinggi Theologia Injili Indonesia, 1997.

Jacobsen, Margareth Baily. Ketika Anak Anda Bertumbuh. Bandung: Kalam Hidup, 1992.

M.Rigs, Ralph. Gembala Sidang Yang Berhasil. Malang: Gandum Mas, 1948.

Narramore, Clyde. Menolong Anak Anda Bertumbuh Dalam Iman. Bandung: Kalam Hidup, t.t.

Pasaribu, Dr. Marulak. Pernikahan Dan Keluarga Kristen. Batu: Departement Literatur YPPII, t.t.

Prince, Derek. Faedah Pentakosta. Jakarta: Yayasan Pekabaran Injil IMANUEL, 1993.

Rinukti, Nunuk. "Peranan Perempuan Menurut Perjanjian Baru Bagi Perkembangan Kepemimpinan Perempuan Di Dalam Gereja." Jurnal Teruna Bhakti 1, no. 1 (2018): 33-41. http://ejournal.stakterunabhakti.ac.id/index.php/teruna/article/view/9.

Rumawak, Zet Luther. Majelis Jemaat GKAI Maranatha Taman Ria. Hari Minggu, Tanggal 12.

Saroi, Andarius. Jemaat GKAI Maranatha Taman Ria. Hari Minggu, Tanggal 12 Juli 2014.

Suryaprawata. Keluargaku. Yogyakarta: Kanisius, 1992. 
Swindoll, Charles C. Anda Dan Anak. Surabaya: YAKIN, 1988.

Tim Penyusun. Katekesasi Pernikahan. Magelang: Departement Pembinaan BPMS GKI Jateng, 1990.

Tong, Stephen. Keluarga Bahagia. Jakarta: Lembaga Reformed Injili Indonesia, 1995.

Trisna, Jonathan A. Konseling Pranikah. Malang: Penerbit Gandum Mas, 1987.

Trisna, Jonathan A. Pernikahan Kristen. Jakarta: Institut Theologia dan Keguruan Indonesia, 2000. 